\title{
Meslek Etiği ve Akademisyenlerin Etik Değerleri Üzerine Nicel Bir Araştırma
}

\author{
DOI: 10.26466/opus.599983 \\ Meral Erdirençelebi* - Berrin Filizöz ${ }^{* *}$ \\ * Dr.Öğretim Üyesi, Necmettin Erbakan Üniversitesi Uygulamalı Bilimler Fakültesi/Konya \\ E-Posta: merginn@hotmail.com \\ ORCID: $0000-0002-7705-6067$ \\ ** Prof. Dr., Sivas Cumhuriyet Üniversitesi, İktisadi İdari Bilimler Fakültesi /Sivas/ Türkiye \\ E-Posta: bfilioz@cumhuriyet.edu.tr \\ ORCID: $\underline{0000-0001-6442-9867}$
}

Öz

Etik, son yillarda her alanda tartışılan konuların başında gelmektedir. Meslek etiği, bir mesleğe üye bireylerin davranış ve tutumların evrensel boyutta ahlaki bir çizgiye kavuşturmak için oluşturulmuş kurallar ve standartlar bütünüdür. Bir meslekte etik ilkelere göre hareket edilmesi bir toplumda etik standartların yerleşmesi açısından destekleyicidir. Akademisyenlerin akademik etik değerlere sahip olmaları ve etik ilkeleri paydaşlarına kazandırabilmeleri son derece önem taşımaktadır. Bu çalışma ile akademisyenlerin etik değerlere dair algı ve tutumlarının demografik değişkenlerine göre farklllık gösterip göstermediği belirlenmeye çalışılmıştır. Araştırma için ana kütle 112 devlet üniversitesi olarak belirlenmiştir. 9 devlet üniversitesinden tesadüfi seçilen 2500 akademisyene ulaşılmaya çalışılmıştır. Ancak toplamda 587 akademisyenden elde edilen veriler değerlendirmeye alınmıştır. Frekans analizi, açıklayıcı ve doğrulayıcı faktör analizleri, korelasyon analizi, kolmogorov-smirnov testi, mann whitney-u testi, kruskal-wallis testi yapılmış ve bulgular yorumlanmıştır. Yapılan korelasyon analizi sonuçlarma göre, akademik etik değer ölçeğinin her bir alt boyutunun birbirleriyle pozitif yönlü ve anlamlı ilişkisi olduğu; araştırma örneklemini oluşturan akademisyenlerin akademik etik değerleri algı ve tutumlarının demografik değişkenlere göre farklllık gösterdiği görülmüştür.

Anahtar Kelimeler: Etik, mesleki etik, akademik etik 


\title{
Professional Ethics and A Quantitative Investigation on The Ethical Values of Academicians
}

*

\begin{abstract}
Ethics has been one of the most discussed issues in recent years. Professional ethics is a set of rules and standards that are created to bring the behaviour and attitudes of the members of a profession to a moral line in a universal dimension. Acting according to ethical principles in a profession is important for establishing ethical standards in a society. It is extremely important for academicians to have ethical values and to teach ethical principles to their stakeholders. In this study, it was tried to determine whether the perceptions and attitudes of academicians about ethical values differ according to demographic variables. The main population for the study was determined as 112 public universities. 2500 randomly selected academicians from 9 state universities were tried to be reached. However, the data obtained from a total of 587 academicians were evaluated. Frequency analysis, explanatory and confirmatory factor analyzes, correlation analysis, Kolmogorov-Smirnov test, Mann Whitney-U test and Krus$\mathrm{kal}$-Wallis test were performed, and the findings were interpreted. According to the results of the correlation analysis, it is seen that each sub-dimension of the academic ethical value scale had a positive and significant relationship with each other; academic ethics values perception and attitudes of academicians who make up the research sample differ according to demographic variables.
\end{abstract}

Keywords: Etichs, Professional Ethics, Ethics in academicians 


\section{Giriş}

Günümüzde iş etiği konusuna olan ilgi artmasına rağmen, iş hayatında etik sorunlar da beraberinde artarak yaşanmaktadır. Toplumsal ahlaki çözülmelerin sözkonusu olduğu son zamanlarda, etik kavramının dinamik tutulması, tüm toplum üyeleri tarafından anlaşılması ve uygulanması gerekmektedir. İş etiği alanlarından birini oluşturan mesleki etik ilkelerine bağlı hareket etmek, rekabet koşullarında başarıyı getirmektedir. Yaşanılan teknolojik gelişmeler sonucu toplum yapısının bilgi toplumuna dönüşmüş olması tüm faaliyetlerin bilgi odaklı olmasını zorunlu hale getirmiştir. Nitekim toplumda bilgiyle en sık uğraşan kişiler bilimin parçası olan akademisyenlerdir. Meslekleri gereği akademisyenler, bilimsel bilgiyi doğru bir biçimde toplamak, oluşturmak, kullanmak ve yaymak sorumluluğunu taşımalıdırlar (Akkaya ve Yıldırım, 2017, s.80). Bu sorumluluğun geliştirilmesinde etik kurallar temel ölçüt olmalıdır.

Literatürde bilimsel araştırma etiği konulu çalışmalar yer almasına rağmen (Köklü, 2003; Bülbül, 2004; Ruacan, 2005; Büken, 2006; Aydın, 2006; Uçak ve Birinci, 2008; Odabaş, 2015; Özcan ve Balc1, 2016), akademisyenlerin tüm akademik etik değerlere yönelik görüşlerinin yer aldığı (nicel ve nitel) çalışma sayısının sınırlı olduğu görülmüştür (Maya, 2013; Sevim, 2014; Aydın vd., 2014; Kırkkılıç vd., 2015). Bu amaçla Türkiye'de bulunan üniversitelerde görevli akademisyenlerin akademik etik değerlere dair algı ve tutumlarının tespiti ve bu düzeylerin demografik değişkenlere göre farklılık taşıyı taşımadığı belirlenmeye çalışılmıştır.

\section{Kavramsal Çerçeve}

Ahlak, insanlara iyi-kötü, doğru-yanlış, güzel-çirkin, erdem ve kusur arasında değerlendirme yapmayı sağlayan yazısız kurallar bütünüdür. Başka bir deyişle ahlak; "İnsanların birbirleriyle veya devletle olan ilişkilerinde kendilerinden yapmaları istenen davranışlarla toplum düzenini sağlayan kurallar ve normlar dizgesidir" (Anonim, 2006, s.4). Kisaca ahlak, birey ve toplumla ilgili sosyal süreçleri kapsayan sosyolojik bir fenomendir ve toplumsal yapıya yön verir (Karabay, 2015: 5). Ahlaki kavramlar ve değerler bütünü bireysel ve zamansal farklılık göstere- 
bilmektedir. Bunun temel nedeni olarak neyin ahlaklı neyin ahlaklı olmadığına dair değerlendirmelerde, dinsel inançlar, kültürel değerler ve hukuki yapının etkili olduğu gösterilebilir (Keskin, 2018: 4). Ahlak, tarihi süreç içerisinde farklı dinlerce, ideolojilerce ve toplum kesimlerince ele alınan bir konu olmuş ve halende konu olmayı sürdürmektedir. Üzerinde durulmasının temel nedeni, yaşanan sorunlara çözüm arayışıdır (Erdoğmuş, vd. 2018, s.12).

Literatürde etik ile ilgili pek çok tanım bulunmakta ve ahlak ile birbiri yerine kullanılmakta olduğu görülmektedir (Mirze, 2010, s.394). İki kavramın karıştırılmasında dilimize yapılan çeviriler etkilidir. Ahlak kavramı, bireylerin sosyal yaşamdaki ilişkilerini inceleyip, düzenleyen bir sistem biçiminde kabul görürken; etik kavramı, iş yaşamındaki davranış biçimlerini ele alarak düzenleyen bir disiplin olarak kabul edilmektedir (Anonim, 2006, s.3). Ek olarak etik kurallar yazılı iken ahlaki kurallar yazılı değildir. Etik, ahlaki tutum, kural ve değerlerin kaynağından hareket eden bir disiplindir (Usta, 2011, s.40). Bu nedenledir ki ahlak ile net bir ayrım yapılamamaktadır.

Etik temelde belirli standartlara dayanmakta, bu standartlar uygulandıkları alanlara göre dört gruba ayrılmaktadır. Bu alt gruplar; kişisel etik, meslek etiği, işletme etiği ya da yönetsel etik ve toplumsal etiktir (Ülgen ve Mirze, 2004, s.448-450). Üst çerçevesi iş etiği tarafından belirlenen ilkeler, meslekler arasında birtakım farklı uygulama ve erdemleri de içerisinde barındırırken (Filizöz, 2011, s.30) aynı zamanda da diğer etik gruplarının standartlarından da etkilenmektedir (Şenturan, 2014, s.104). Mesleki etik, ortaya koyulan mesleki davranışla ilgili iyi-kötü, doğruyanlış, haklı-haksız, tüm inançları esas alan ilkeler, değerler, kurallar ve standartlar bütünüdür. Mesleki etik, meslek üyelerinin kişisel eğilimlerini kısıtlayan, kapsadığı kurallara uymayanları meslekten uzaklaştıran, mesleki rekabet boyutlarını düzenleyen, yazılı etik kurallar bütünüdür. Bu etik kuralların bir kısmı vicdani yargılara diğer kısmı ise o işin bağlı olduğu oda, devlet, uluslararası örgütler tarafından düzenlenmiş yazılı birtakım standartlara dayanmaktadır. Temel amacı, meslek mensuplarını görevlerini yerine getirirken toplum güvenini sağlayan davranış kuralları ile yönlendirmek ve yönetilmesini desteklemektir (Keskin, 2018, s.33-34). Meslek etiğinin en temel amacı, dünyanın her yerinde, aynı meslek 
mensuplarının mesleki etik kurallarına uygun hareket etmelerini sağlamaktır.

Mesleki etik ülkemizde de farklı meslek dallarında önemini artırarak gündemde kalmaktadır. Meslekle uyuşmayan yanlış ya da eksik davranışlar o mesleğin toplum gözünde saygınlığını zedelemektedir. Özellikle kurumlarda yolsuzluk ve diğer ahlak dışı davranışların artış göstermesinin araştırmalarda ve basında haber olarak sıkça yer alması konunun daha da önem kazanmasına yol açmıştır. Yaşanan bu gelişmeler neticesinde pek çok meslek kendi etik standartlarını geliştirmiştir. Tıp etiği, öğretmenlik meslek etiği, polis meslek etiği, finansal etik, bilimsel yayın etiği gibi pek çok etik standartlar hayata geçirilmiştir (Karabay, 2015, s.18-19). Mesleki etik olarak ele alınabilecek başlıklardan birisi de kuşkusuz akademik etiktir. YÖK'ün yapmış olduğu tanıma göre akademik etik; "Akademisyenlerin bilimsel çalışmaların üretilmesi, sunulması ve değerlendirilmesinde, toplumun farklı paydaşları ile ilişkilerinde, ödüllendirilme ve yükseltilme aşamalarında, bilim kurumları ve üniversitelerin bilimsel yetkinliğe dayalı yapılandırılması ile bilim insanlarının yetiştirilmesi süreçlerinde etik davranış kurallarına uymayı ifade etmektedir" (Yükseköğretim,...,2014). Son zamanlarda hızlı teknolojik gelişimle beraber diğer mesleklerde olduğu gibi akademik çalışma ve etkinliklerde de birtakım etik dışı davranışların arttığı görülmektedir.

Akademisyenlik olarak ifade edilen akademik mesleği, öğretim elemanlığı ve bilimsel mesleğin bir üniversitede yürütülmesidir (Tülübaş ve Görtürk, 2018, s. 38). Akademisyenlik mesleği temelde üç rolü yerine getirmektedir. Bunlar; bilimsel araştırma, eğitim-öğretim ve topluma hizmettir. Bilimsel araştırma faaliyetleri ile toplum tarafından ihtiyaç duyulan bilginin sistematik biçimde toplanması ve mesleki bilginin artırılması görevleri gerçekleştirilirken; eğitim-öğretim (öğrencilere ve bireylere) ile bilimsel araştırma faaliyetleri sayesinde toplanan bilginin günlük hayata aktarılması söz konusudur (Dill, 1982). Akademisyen, bilimsel konularla ilgili yaptığı çalışmalarla toplumsal gelişime katkı sağlarken aynı zamanda topluma örnek olma gibi önemli bir rolü de üstlenmektedir. Akademisyenlik mesleği ile ilgili davranış örüntüleri diğer meslek dallarında da olduğu üzere bir takım değerler ve etik kodlara dayanmaktadır. "Akademik etik değerler, problemin ya da ihtiyacın belirlenmesiyle başlayıp elde edilen bilgilerin hedef kitleyle paylaşılmasına kadar devam 
eden süreçte göz önünde bulundurulması gereken davranış örüntüleridir". Akademik etik kodların temel amacı, hem bilimsel bilgi birikiminin araştırma ve yayın yoluyla somutlaştırılması hem de bu bilgilerin paydaşlarla paylaşılması süreçlerinde etik dışı davranış sergilenmesinin mesleğe ve topluma vereceği zararların önüne geçmektir (Aydın, 2006; Erdem, 2012; Ertekin, vd., 2002; akt. Özcan ve Balc1, 2016, s.91).

Akademik etik değerler üzerinde sıkça yazılıp çizilen bilimsel bir araştırmanın yapılması süreciyle sınırlı değildir. Akademik etik değerlerin alt boyutları: "bilimsel araştırma yapma, meslektaşlarla olan akademik ilişkiler, çalışılan kuruma yönelik sorumluluklar, hedef kitlesiyle yani öğrencilerle öğretim sürecine yönelik ilişkiler ve toplumla sürdürülen ilişkileri kapsamaktadır (Sevim, 2014, s.945). Literatürde yer alan çalışmalar incelendiğinde, akademik etik boyutlarından bilimsel araştırma yapma alt boyutuna ilişkin; gerçeğe aykırı açılama yapma, sahtecilik, yayın intihalleri, gizli amaç gütme, ikram yazarlık, başkalarının çalışmalarını tekrarlama, dilimleme, yayın etiğine aykırı hareket etme, izinsiz kullanma, özensiz ve disiplinsiz çalışma, taraflı yayıncılık vb. etik dışı davranışlar yer almaktadır (Büken, 2006; Maya, 2013; Özcan ve Balc1, 2016; Akkaya ve Yıldırım, 2017; Ruacan, 2005). Meslektaşlarla olan akademik ilişkilerde yaşanan etik dışı davranışlar arasında; fikri mülkiyete saygısızlık, fikir hırsızlığı, kayırmacılık, adil eleştirel değerlendirme yapmama, meslektaşı hakkında bilerek yanlış, kötü niyetli açıklamada bulunma vb. yer almaktadır (Gerçek, vd., 2011, s.83). Çalışılan kuruma yönelik sorumluluklara dair, kurumun akademisyenden beklediği desteği sunmama, etkinliklere katılımda kurumun adını geçirmeme, vb. gibi etik dışı davranışlar söz konusudur. Ĕ̆itim-öğretim sürecine yönelik ilişkilerde etik dışı davranışlar arasında; bu süreci önemsememe (yenilikleri takip etmemek), ders sürelerine riayet etmeme, girmediği halde o dersin ücretini alma, derse kendisi yerine bir başkasını gönderme, dersle ilgili öğrencide merak ve ilgi uyandırmama, öğrencilerle ilişkilerini kişisel kazançları için kullanma (Saddleback College, 2001), öğrenci merkezli yerine öğretmen merkezli olma, öğrenci değerlendirmede subjektif davranma, uzmanlık alanı dışında derse girme, danışmanlık görevini ihmal etme, öğrenciye dili, dini, ırkı, medeni hali vb. sebeplerle haksız yere müdahale etme vb. yer almaktadır (Büken, 2006; Owen ve Zwhar-Castro, 2007; Maya, 2013; Gerçek, vd., 2011). Toplumla sürdürülen ilişkilere yönelik etik dışı davranışlar 
arasında, üniversite-toplum ilişkilerinde olumlu tutum takınmama, üniversitenin temsilcisi olarak üstlendiği görevlerde kişisel görüş ve düşüncelerini üniversiteninmiş gibi gösterme (Saddleback College, 2001), farklı inanç, düşüncedeki kişilere saygılı ve adil olmama (Gerçek, vd., 2011, s.83) vb. yer almaktadır. Öte yandan akademisyenlerin yaşamış/yaşamakta oldukları zorluklar, ilgi alanları ve demografik özellikleri, mesleki rol ve sorumluluklarını yerine getirirken iş kalitesini etkilemektedir (Baldwin vd., 2005).

\section{Metodoloji}

\section{Araştırmanın Amacı, Evren ve Örneklemi}

$\mathrm{Bu}$ araştırmanın temel amacı, akademisyenlerin akademik etik değerleri alg1 ve tutum düzeylerinin belirlenmesi ve demografik değişkenlere göre bu düzeylerinin farklılaşıp farklılaşmadığını ortaya koymaktır.

Araştırmanın temel amacı doğrultusunda aşağıda yer alan hipotezler oluşturulmuştur:

- $\mathrm{H}_{1}=$ Akademisyenlerin akademik etik değerleri alg1 ve tutum düzeyleri cinsiyet değişkenine göre farklılık göstermektedir.

- $\mathrm{H}_{2}=$ Akademisyenlerin akademik etik değerleri alg1 ve tutum düzeyleri medeniyet durumu değişkenine göre farklılık göstermektedir.

- $\mathrm{H}_{3}=$ Akademisyenlerin akademik etik değerleri alg1 ve tutum düzeyleri yaş değişkenine göre farklılık göstermektedir.

- $\mathrm{H}_{4}=$ Akademisyenlerin akademik etik değerleri alg1 ve tutum düzeyleri yurt dışı görev değişkenine göre farklılık göstermektedir.

- $\mathrm{H}_{5}=$ Akademisyenlerin akademik etik değerleri alg1 ve tutum düzeyleri mesleki kıdem yılı değişkenine göre farklılık göstermektedir.

- $\mathrm{H}_{6}=$ Akademisyenlerin akademik etik değerleri alg1 ve tutum düzeyleri branş değişkenine göre farklılık göstermektedir. 
Araştırma amacı doğrultusunda 112 devlet üniversitesi içinden 9 devlet üniversitesinde görev yapan ve tesadüfen seçilen 2500 akademisyene ulaşılmaya çalışılmıştır. Seçilen akademisyenlere anket formu mail yoluyla ya da yüz yüze dağıtılmıştır. Geri dönen 600 adet anketin eksik olan 13 adeti çıkarılarak kalan 587 adet anket analize alınmıştır.

\section{Veri Toplama Yöntemi ve Kullanılan Ölçekler}

Nicel araştırma tekniklerinden anket yöntemi ile veriler toplanmıştır. Anket iki bölüm ve 62 ifadeden oluşmaktadır. Birinci bölümde katılımcıların demografik özellikleri ile ilgili 12 ifade yer almıştır. İkinci bölümde ise akademisyenlerin akademik etik değerleri algı ve tutum seviyelerini belirleyebilmek için Sevim tarafından geliştirilmiş (2014) olan "Akademik Etik Değerler Ölçeği” kullanılmıştır. Ölçek 50 önermeden oluşmaktadır. Araştırma kapsamında toplanan verilerin analizinde SPSS 22 ve LISREL 9.1'de kullanılmıştır. Analizlerden önce araştırmada kullanılan ölçeğin güvenilirliğini test etmek için madde-bütün korelasyonuna bakılarak Cronbach's Alpha katsayısı hesaplanmıştır. Frekans analizi, açıklayıcı ve doğrulayıcı faktör analizleri, korelasyon analizi, kolmogorov-smirnov testi, mann whitney-u testi, kruskal-wallis testi yapılmıştır.

\section{Araştırmanın Sinırlılığı}

Çalışmanın sınırlılıkları arasında en önemlileri, zaman ve ekonomik sınırlılıklardır. Veriler Mayıs-Aralık 2018 tarihleri arasında toplanmıştır. Ayrıca akademisyenlerin gerek kendileri gerekse çalıştıkları üniversite ile ilgili olumsuz bir kanı oluşturmamak amacıyla anket sorularına yanlı cevap verebilecekleri muhtemeldir. 


\section{Bulgular}

\section{Demografik Bulgular}

Araştırmaya kapsamında yer alan 587 akademisyenin demografik bilgileri Tablo 1.'de yer almaktadir.

Tablo 1. Demografik Özelliklerin Frekans Dă̆ılımları

\begin{tabular}{|c|c|c|c|c|c|c|c|}
\hline Parametreler & & Frekansı & Yüzde & Paramet & reler & Frekansi & Yüzde \\
\hline \multirow{8}{*}{ Yaş } & $25-29$ & 107 & 18,2 & \multirow{7}{*}{ Branş } & İktisat & 38 & 6,5 \\
\hline & $30-34$ & 75 & 12,8 & & İşletme & 79 & 13,5 \\
\hline & $35-39$ & 154 & 26,2 & & Mühendislik & 247 & 42,1 \\
\hline & $40-44$ & 52 & 8,9 & & Tip & 188 & 32,0 \\
\hline & $45-49$ & 97 & 16,5 & & Tarih & 6 & 1,0 \\
\hline & $50-54$ & 65 & 11,1 & & Felsefe & 7 & 1,2 \\
\hline & $55-59$ & 30 & 5,1 & & Uluslararası İliş. & 22 & 3,7 \\
\hline & $60-64$ & 7 & 1,2 & \multirow{6}{*}{ Unvan } & Prof. Dr. & 125 & 21,3 \\
\hline \multirow[b]{2}{*}{ Cinsiyet } & Bayan & 180 & 30,7 & & Doç. Dr. & 142 & 24,2 \\
\hline & Erkek & 407 & 69,3 & & Dr. Öğr. Üyesi & 152 & 25,9 \\
\hline \multirow{2}{*}{$\begin{array}{l}\text { Medeni } \\
\text { Durum }\end{array}$} & Bekâr & 201 & 34,2 & & Öğr. Gör. & 65 & 11,1 \\
\hline & Evli & 386 & 65,8 & & Okutman & 1 & ,2 \\
\hline \multirow{3}{*}{$\begin{array}{c}\text { Öğrenim } \\
\text { Durumu }\end{array}$} & Lisans & 35 & 6,0 & & Araştırma Görev. & 102 & 17,3 \\
\hline & $\begin{array}{l}\text { Yük. } \\
\text { Lisans }\end{array}$ & 177 & 30,2 & \multirow{9}{*}{$\begin{array}{l}\text { Görev } \\
\text { Yapılan } \\
\text { Üniv. }\end{array}$} & Selçuk Üniv. & 143 & 24,4 \\
\hline & Doktora & 375 & 63,8 & & $\begin{array}{l}\text { Ondokuz } \\
\text { Mayıs Üniv. }\end{array}$ & 14 & 2,4 \\
\hline \multirow{5}{*}{ İş Tecrübesi } & $1-5$ yil & 94 & 16,0 & & Gazi Üniv. & 160 & 27,3 \\
\hline & $6-10$ yıl & 190 & 32,5 & & $\begin{array}{l}\text { Necmettin } \\
\text { Erbakan Üniv. }\end{array}$ & 193 & 32,9 \\
\hline & 11-15 yil & 100 & 17,0 & & Amasya Üniv. & 12 & 2,1 \\
\hline & $16-20 \mathrm{y} 1 \mathrm{l}$ & 110 & 18,7 & & Akdeniz Üniv. & 19 & 3,2 \\
\hline & 20 ve + & 93 & 15,8 & & Batman Üniv. & 12 & 2,0 \\
\hline \multirow{2}{*}{ İdari Görev } & Evet & 92 & 15,7 & & Hacettepe Üniv. & 11 & 1,8 \\
\hline & Hayır & 495 & 84,3 & & Cumhuriyet Üniv. & 23 & 3,9 \\
\hline \multirow{2}{*}{$\begin{array}{l}\text { Yurt Dişı } \\
\text { Görev }\end{array}$} & Evet & 118 & 20,1 & \multicolumn{2}{|l|}{ Toplam } & 587 & 100,00 \\
\hline & Hayır & 469 & 79,9 & & & & \\
\hline Toplam & & 587 & 100,00 & & & & \\
\hline
\end{tabular}




\section{Veri Toplama Aracının Güvenirlik ve Geçerliği}

Akademik etik değerler ölçeğinin güvenirliğini (içsel tutarlılığının) görmek için bakılan Cronbach's Alpha katsayısının 0,70'den büyük olduğu görülmüştür.

Tablo 2. Araştırmada Kullanılan Ölçeğin Güvenirlik Katsayısı

\begin{tabular}{|c|c|c|c|c|}
\hline Akademik Etik Değerler Ölçeği & $\begin{array}{l}\text { Ölçüm } \\
\text { Aralığ1 }\end{array}$ & $\begin{array}{l}\text { Cronbach's } \\
\text { Katsayıs1 }\end{array}$ & Alpha & $\begin{array}{l}\text { KMO } \\
\text { Değeri }\end{array}$ \\
\hline Analiz başlangıcında ifade sayısı:50 & $\begin{array}{l}\text { 5'li ölçek (1-5 } \\
\text { arası) }\end{array}$ & 702 & & 678 \\
\hline $\begin{array}{l}\text { Analiz sırasında düşük değerli } \\
\text { ifadeler çıkarıldıktan sonra ifade } \\
\text { sayısı:42 }\end{array}$ & $\begin{array}{l}\text { 5'li ölçek (1-5 } \\
\text { arası) }\end{array}$ & 749 & & ,725 \\
\hline
\end{tabular}

\section{Açıklayıcı ve Doğrulayıcı Faktör Analizleri}

Akademik etik değerler ölçeğinin alt boyutlarını belirlemek için açıklayıcı faktör analizi uygulanmıştır (bkz. Tablo 3).

Analiz sonucunda faktörlerin yüksek değerleri olduğu gözlemlenmiştir. Ölçekte yer alan M9, M10, B9, Ç2, Ö13, T7, T8 düşük değer taşıdıklarından sırasıyla analizden çıkartılmışlardır. Ayrıca Ö12 iki faktörde de yakın değerler taşıdığı için analizden çıkarılmıştır. Analiz sonucunda toplam varyansı \% 67,434 olan beş alt faktör oluşmuştur. Birinci faktöre Mesleğe yönelik değerler (MYD), 2. faktöre Bilimsel araştırmaya yönelik değerler (BAYD), 3. faktöre Çalışılan kuruma yönelik değerler (CKYD), 4. faktöre Öğretim sürecine yönelik değerler (ÖSYD), 5. faktöre Topluma yönelik değerler (TYD) adı verilmiştir. (Analizde öz değer: 1 ve üzeri; faktör yükü: 0,50 ve üzeri; açılanan varyans oranı: toplam varyansın $2 / 3^{\prime}$ ü esas alınmıştır). 
Tablo 3. Akademik Etik Değerler Ölçeği Açıklayıcı Faktör Analizi Sonuçları

\begin{tabular}{|c|c|c|c|c|c|}
\hline Alt Boyut & Madde & Faktör Yükü & Varyans & Cronbach's Alpha & Öz Değer \\
\hline \multirow{8}{*}{$\begin{array}{l}\text { Meslektaşa } \\
\text { yönelik değerler } \\
\text { (MYD) }\end{array}$} & M5 & .916 & \multirow{8}{*}{17,603} & \multirow{8}{*}{,743 } & \multirow{8}{*}{8,041} \\
\hline & M4 & .870 & & & \\
\hline & M7 & .835 & & & \\
\hline & M1 & .753 & & & \\
\hline & M2 & .733 & & & \\
\hline & M3 & .724 & & & \\
\hline & M8 & .723 & & & \\
\hline & M6 & .577 & & & \\
\hline \multirow{8}{*}{$\begin{array}{l}\text { Bilimsel } \\
\text { araştırmaya } \\
\text { yönelik değerler } \\
\text { (BAYD) }\end{array}$} & B6 & ,746 & \multirow{8}{*}{14,531} & \multirow{8}{*}{,833 } & \multirow{8}{*}{5,813} \\
\hline & B2 & ,742 & & & \\
\hline & B3 & ,712 & & & \\
\hline & B1 & ,699 & & & \\
\hline & B5 & 696 & & & \\
\hline & B7 & ,557 & & & \\
\hline & B4 & 556 & & & \\
\hline & B8 & ,504 & & & \\
\hline \multirow{8}{*}{$\begin{array}{l}\text { Çalışılan kuruma } \\
\text { yönelik değerler } \\
\text { (CKYD) }\end{array}$} & Ç1 & .776 & \multirow{8}{*}{13,234} & \multirow{8}{*}{,710 } & \multirow{8}{*}{5,293} \\
\hline & Ç8 & .667 & & & \\
\hline & Ç7 & 645 & & & \\
\hline & Ç5 & 639 & & & \\
\hline & Ç9 & 638 & & & \\
\hline & Ç3 & 553 & & & \\
\hline & Ç6 &, 547 & & & \\
\hline & Ç4 &, 535 & & & \\
\hline \multirow{12}{*}{$\begin{array}{l}\text { Öğretim sürecine } \\
\text { yönelik değerler } \\
\text { (ÖSYD) }\end{array}$} & Ö4 & 831 & \multirow{12}{*}{11,954} & \multirow{12}{*}{,735 } & \multirow{12}{*}{4,782} \\
\hline & Ö9 & 822 & & & \\
\hline & Ö8 & 785 & & & \\
\hline & Ö14 & ,783 & & & \\
\hline & Ö3 &, 700 & & & \\
\hline & Ö7 & 686 & & & \\
\hline & Ö11 & 679 & & & \\
\hline & Ö10 & 628 & & & \\
\hline & Ö6 & 607 & & & \\
\hline & Ö2 & 586 & & & \\
\hline & Ö5 &, 582 & & & \\
\hline & Ö1 &, 560 & & & \\
\hline \multirow{6}{*}{$\begin{array}{l}\text { Topluma } \\
\text { yönelik değerler } \\
\text { (TYD) }\end{array}$} & T3 & 827 & \multirow{6}{*}{$\begin{array}{l}\text { 10,112 } \\
\text { Toplam: } \\
67,434\end{array}$} & \multirow{6}{*}{, 815} & \multirow{6}{*}{1,307} \\
\hline & $\mathrm{T} 2$ & 801 & & & \\
\hline & $\mathrm{T} 4$ & ,774 & & & \\
\hline & $\mathrm{T} 1$ & 705 & & & \\
\hline & $\mathrm{T} 5$ & 652 & & & \\
\hline & T6 & 629 & & & \\
\hline
\end{tabular}


Tablo 4. Akademik Etik Değerler Ölçeği Doğrulayıcı Faktör Analizi Uyum İyiliği Sonuçları(Kaynak: Seçer, 2013, s.152)

\begin{tabular}{lll}
\hline Uyum İndeksi & Kabul İçin Kesme Noktaları & Ölçeğin Uyum İndeksleri \\
\hline $\boldsymbol{\varkappa}^{2} / \mathbf{s d}$ & $\boldsymbol{\varkappa}^{2} / \mathrm{sd}<4$ olmalıdır & $\mathbf{2 , 9 8}$ \\
\hline RMSEA & $0,00<0,05=\mathrm{MU} \leq 0,05-0,08=\mathrm{KEU}$ & $\mathbf{0 , 0 7} \mathrm{KEU}$ \\
\hline NFI & $\geq 0,95=\mathrm{MU} \geq 0,90=\mathrm{KEU}$ & $\mathbf{0 , 9 6} \mathrm{MU}$ \\
\hline NNFI & $\geq 0,95=\mathrm{MU} \geq 0,90=\mathrm{KEU}$ & $\mathbf{0 , 9 6 \mathrm { MU }}$ \\
\hline CFI & $\geq 0,97=\mathrm{MU} \geq 0,95=\mathrm{KEU}$ & $\mathbf{0 , 9 6} \mathrm{KEU}$ \\
\hline RFI & $\geq 0,95=\mathrm{MU} \geq 0,90=\mathrm{KEU}$ & $\mathbf{0 , 9 6 \mathrm { MU }}$ \\
\hline GFI & $\geq 0,90=\mathrm{MU} \quad \geq 0,85=\mathrm{KEU}$ & $\mathbf{0 , 9 0} \mathrm{MU}$ \\
\hline AGFI & $\geq 0,90=\mathrm{MU} \geq 0,85=\mathrm{KEU}$ & $\mathbf{0 , 8 8} \mathrm{KEU}$ \\
\hline IFI & $\geq 0,95=\mathrm{MU} \geq 0,90=\mathrm{KEU}$ & $\mathbf{0 , 9 6 \mathrm { MU }}$ \\
\hline
\end{tabular}

(KEU = Kabul edilebilir uyum, MU= mükemmel uyum)

Tablo 4' de görüldüğü üzere ölçeğin uyum değerleri istatistiksel olarak anlamlı ve geçerli olduğunu ispat etmektedir. Tablo 5 'te doğrulayıcı faktör analizi sonucunda faktörlerin aldıkları değerler görülmektedir.

Tablo 5. Akademik Etik Değerler Ölçeği Doğrulayıcı Faktör Analizi Sonuçları

\begin{tabular}{|c|c|c|c|}
\hline Alt Boyutlar & Madde & Std. Reg. Ağırlığ1 & T Değeri \\
\hline \multirow{8}{*}{$\begin{array}{l}\text { Faktör 1: } \\
\text { Meslektaşa yönelikdeğerler } \\
\text { (MYD) }\end{array}$} & M1 & 0,90 & 13,87 \\
\hline & M2 & 0,91 & 14,95 \\
\hline & M3 & 0,83 & 13,02 \\
\hline & M4 & 0,85 & 13,46 \\
\hline & M5 & 0,72 & 11,39 \\
\hline & M6 & 0,77 & 12,41 \\
\hline & M7 & 0,71 & 11,00 \\
\hline & M8 & 0,60 & 10,73 \\
\hline \multirow{8}{*}{$\begin{array}{l}\text { Faktör 2: } \\
\text { Bilimsel araştırmaya yönelik değerler (BAYD) }\end{array}$} & B1 & 0,81 & 13,08 \\
\hline & $\mathrm{B} 2$ & 0,66 & 8,73 \\
\hline & B3 & 0,74 & 11,16 \\
\hline & B4 & 0,77 & 11,51 \\
\hline & B5 & 0,64 & 8,05 \\
\hline & B6 & 0,69 & 9,83 \\
\hline & B7 & 0,56 & 7,79 \\
\hline & B8 & 0,53 & 7,28 \\
\hline \multirow{9}{*}{$\begin{array}{l}\text { Faktör 3: } \\
\text { Çalışılan kuruma yönelik değerler (CKYD) }\end{array}$} & Ç1 & 0,66 & 11,58 \\
\hline & Ç3 & 0,71 & 12,03 \\
\hline & Ç4 & 0,67 & 11,65 \\
\hline & Ç6 & 0,74 & 13,39 \\
\hline & Ç5 & 0,68 & 12,34 \\
\hline & Ç7 & 0,63 & 11,02 \\
\hline & Ç8 & 0,60 & 10,30 \\
\hline & Ç9 & 0,55 & 9,11 \\
\hline & Ö1 & 0,54 & 10,83 \\
\hline
\end{tabular}


Faktör 4:

Öğretim sürecine yönelik değerler (ÖSYD)

\begin{tabular}{lll} 
Ö2 & 0,82 & 14,30 \\
\hline Ö3 & 0,85 & 15,04 \\
\hline Ö4 & 0,77 & 13,42 \\
\hline Ö5 & 0,58 & 11,26 \\
\hline Ö6 & 0,66 & 11,93 \\
\hline Ö7 & 0,73 & 12,85 \\
\hline Ö8 & 0,79 & 13,55 \\
\hline Ö9 & 0,70 & 12,03 \\
\hline Ö10 & 0,61 & 11,56 \\
\hline Ö11 & 0,59 & 11,32 \\
\hline Ö14 & 0,75 & 13,23 \\
\hline T1 & 0,82 & 14,36 \\
\hline T2 & 0,85 & 15,20 \\
\hline T3 & 0,76 & 13,54 \\
\hline T4 & 0,71 & 13,02 \\
\hline T5 & 0,63 & 11,26 \\
\hline T6 & 0,58 & 10,87 \\
\hline
\end{tabular}

Faktör 5:

Topluma yönelik değerler (TYD)

\section{Korelasyon Analizi}

Akademik etik değerler ölçeğinin alt boyutları arasında ki ilişkileri görmek için Pearson Korelasyon analizi uygulanmıştır. Analiz sonuçları aşağıdaki Tablo 6.'da görülmektedir.

Tablo 6. Korelasyon Analizi

\begin{tabular}{lllllll}
\hline & & MYD & BAYD & CKYD & ÖSYD & TYD \\
\hline MYD & $\mathrm{r}$ & 1 & & & & \\
\hline BAYD & $\mathrm{r}$ &, 230 & 1 & & & \\
\hline CKYD & $\mathrm{r}$ &, 795 &, $490^{*}$ & 1 & & \\
\hline ÖSYD & $\mathrm{r}$ &, 478 &, 520 &, 479 & 1 & \\
\hline TYD & $\mathrm{r}$ &, 367 &, $321^{*}$ &, 482 &, 436 & 1 \\
\hline
\end{tabular}

(MYD: Meslektaşa yönelik değerler, BAYD: Bilimsel araştırmaya yönelik değerler, CKYD: Çalışılan kuruma yönelik değerler, ÖSYD: Öğretim sürecine yönelik değerler, TYD: Topluma yönelik değerler) Not:1*Korelasyon 0,05 düzeyinde anlaml diğerleri 0,01 düzeyinde anlamlıdır.

Tablo 6'daki sonuçlar, akademik etik değerler ölçeğinin her bir alt boyutunun birbiriyle pozitif yönlü ve anlamlı ilişkisi olduğunu göstermektedir. En yüksek ilişki (,795) çalışılan kuruma yönelik değerler ile meslektaşa yönelik değerler arasında görülmektedir. 


\section{Kolmogorov-Smirnov Testi}

Akademik etik değerler ölçeğinin alt boyut değerlerinin normal dağglım sergileyip sergilemediğini görmek için tek örneklem KolmogorovSmirnov testi uygulanmıştır. $\mathrm{Bu}$ analiz sonucunda elde edilen $\mathrm{p}$ değerlerine (anlamlılık değeri) göre $(p=0,000<0,05)$, tüm alt boyutlardaki değerlerin normal dağılıma uygunluk göstermediği belirlenmiştir.

Tablo 7. Kolmogorov-Smirnov Test Sonuçları

\begin{tabular}{|c|c|c|c|c|c|c|}
\hline \multicolumn{7}{|c|}{ One-SampleKolmogorov-Smirnov Test } \\
\hline & & BAYD & MYD & CKYD & TYD & ÖSYD \\
\hline \multicolumn{2}{|l|}{$\mathrm{N}$} & 587 & 587 & 587 & 587 & 587 \\
\hline \multirow{2}{*}{$\begin{array}{l}\text { Normal } \\
\text { Parameters }{ }^{a, b}\end{array}$} & Ortalama & 20,5179 & 36,5707 & 29,1687 & 28,4412 & 57,2675 \\
\hline & Standart Sapma & 4,06780 & 5,83385 & 5,71900 & 4,96244 & 6,62360 \\
\hline \multirow{3}{*}{$\begin{array}{l}\text { Most } \\
\text { Extreme } \\
\text { Differences }\end{array}$} & Absolute & ,155 & 188 & ,210 &, 134 & ,123 \\
\hline & Positive & 155 & ,108 & 131 & ,119 & 117 \\
\hline & Negative &,- 079 &,- 188 &,- 210 &,- 134 &,- 123 \\
\hline \multicolumn{2}{|c|}{ Kolmogorov-Smirnov Z } & 3,757 & 4,566 & 5,086 & 3,252 & 2,971 \\
\hline \multicolumn{2}{|c|}{ Asymp. Sig. (2-tailed) } & 000 & 000 & 000 & 000 & 000 \\
\hline
\end{tabular}

a. Test distribution is Normal.

b. Calculatedfromdata.

(BAYD:Bilimsel araştırmaya yönelik değerler, MYD: Meslektaşa yönelik değerler, CKYD: Çalışılan kuruma yönelik değgerler, TYD: Topluma yönelik değerler, ÖSYD: Öğretim sürecine yönelik değerler)

Bunu takiben, akademik etik değerler ölçeğinin tüm alt boyutlarının cinsiyet, medeni durum ve yurt dişında görev yapma durumu değişkenlerine göre ortalama sıra değerleri arasında fark olup olmadığının testi için non-parametrik bir test olan Mann Whitney-U testi; diğer demografik değişkenler olan yaş, meslekteki kıdem yılı ve branş değişkenlerine göre alt boyutların ortalama sıra değerleri arasında fark olup olmadığının testi için non-parametrik bir test olan Kruskal-Wallis testi yapılmıştır. Bu analiz sonuçları aşağıda sırasıyla tablolar halinde verilmiştir. 
Tablo 8. Cinsiyet Değişkeni İçin Mann Whitney-U Testi Sonuçları

\begin{tabular}{|c|c|c|c|c|c|}
\hline \multicolumn{6}{|l|}{ Grup İstatistikleri } \\
\hline & Cinsiyet & $\mathbf{N}$ & Ortalama & Standart & Standart \\
\hline & & & & Hata & Hata \\
\hline \multirow[t]{2}{*}{ BAYD } & Bayan & 180 & 20,4944 & 4,38318 & ,32670 \\
\hline & Erkek & 407 & 20,5283 & 3,92586 & , 19460 \\
\hline \multirow[t]{2}{*}{ MYD } & Bayan & 180 & 35,7556 & 6,62619 & ,49389 \\
\hline & Erkek & 407 & 36,9312 & 5,41665 & 26849 \\
\hline \multirow[t]{2}{*}{ CKYD } & Bayan & 180 & 28,7167 & 6,15287 & ,45861 \\
\hline & Erkek & 407 & 29,3686 & 5,51235 & ,27324 \\
\hline \multirow[t]{2}{*}{ TYD } & Bayan & 180 & 28,6056 & 5,36229 & ,39968 \\
\hline & Erkek & 407 & 28,3686 & 4,78007 & ,23694 \\
\hline \multirow[t]{2}{*}{ ÖSYD } & Bayan & 180 & 56,3111 & 7,55042 &, 56277 \\
\hline & Erkek & 407 & 57,6904 & 6,13216 & ,30396 \\
\hline \multicolumn{6}{|l|}{ Test İstatistikleri } \\
\hline & BAYD & MYD & CKYD & TYD & ÖSYD \\
\hline Mann-Whitney U & 36352,500 & 32678,000 & 33024,500 & 36345,000 & 32747,500 \\
\hline Wilcoxon W & 52642,500 & 48968,000 & 49314,500 & 119373,000 & 49037,500 \\
\hline $\mathrm{Z}$ &,- 147 & $-2,095$ & $-1,945$ &,- 152 & $-2,058$ \\
\hline Asymp.Sig.(2-tailed) & 883 &, 036 & 052 & 879 &, 040 \\
\hline a. Grup Değişkeni: ci & & & & & \\
\hline
\end{tabular}

Mann Whitney-U Testi $p<0.05$

Tablo 8'de görüldüğü üzere örneklem grubunu oluşturan akademisyenlerin, akademik etik değerler alt boyut ortalamalarının cinsiyete göre değişip değişmediğini tespit etmek için mann whitney-u testi uygulanmıştır. Elde edilen sonuçlara göre \%95 anlam düzeyinde meslektaşa yönelik değerler ve öğretim sürecine yönelik değerler alt boyutlarının ortalamasınn cinsiyet değişkeninden etkilendiği tespit edilmiştir. Anlamlılık değerleri $(p<(\alpha=0.05))$ olduğu için cinsiyet değişkeni bu alt boyutları etkilemektedir. Diğer alt boyutların ortalamasının cinsiyet değişkeninden etkilenmediği tespit edilmiştir. Anlamlılık değerleri $(p>(\alpha=0.05))$ olduğu için cinsiyet değişkeni bu alt boyutları etkilememektedir.

Tablo 9. Medeni Durum Değişkeni İçin Mann Whitney-U Testi Sonuçları Grup İstatistikleri

\begin{tabular}{llllll}
\hline & Medeni hal & N & Ortalama & Standart Sapma & Standart Hata \\
\hline \multirow{2}{*}{ BAYD } & Evli & 386 & 20,5026 & 4,06266 &, 20678 \\
\cline { 2 - 6 } & Bekâr & 201 & 20,5473 & 4,08766 &, 28832 \\
\hline \multirow{2}{*}{ MYD } & Evli & 386 & 36,9948 & 5,67702 &, 28895 \\
\cline { 2 - 6 } & Bekâr & 201 & 35,7562 & 6,05519 &, 42710 \\
\hline \multirow{2}{*}{ CKYD } & Evli & 386 & 29,3523 & 5,79029 &, 29472 \\
\hline
\end{tabular}




\begin{tabular}{|c|c|c|c|c|c|c|c|}
\hline \multirow{3}{*}{ TYD } & Bekâr & 201 & 28,8159 & \multicolumn{2}{|c|}{5,57682} & ,39336 & \\
\hline & Evli & 386 & 28,6477 & \multicolumn{2}{|c|}{5,06941} & 25803 & \\
\hline & Bekâr & 201 & 28,0448 & \multicolumn{2}{|c|}{4,73740} & ,33415 & \\
\hline \multirow[t]{2}{*}{ ÖSYD } & Evli & 386 & 57,6062 & \multicolumn{2}{|c|}{6,36470} & ,32395 & \\
\hline & Bekâr & 201 & 56,6169 & \multicolumn{2}{|c|}{7,06523} & ,49834 & \\
\hline \multicolumn{8}{|c|}{ Test İstatistikleri } \\
\hline & & \multicolumn{2}{|c|}{ BAYD } & MYD & CKYD & TYD & ÖSYD \\
\hline \multicolumn{2}{|c|}{ Mann-Whitney U } & \multicolumn{2}{|c|}{38269,000} & 34233,000 & 36354,000 & 36567,500 & 36445,000 \\
\hline \multicolumn{2}{|c|}{ Wilcoxon W } & \multicolumn{2}{|c|}{112960,000} & 54534,000 & 56655,000 & 56868,500 & 56746,000 \\
\hline \multicolumn{2}{|c|}{$\mathrm{Z}$} & \multicolumn{2}{|c|}{,- 270} & $-2,349$ & $-1,278$ & $-1,151$ & $-1,209$ \\
\hline \multicolumn{2}{|c|}{ Asymp. Sig. (2-tailed) } & \multicolumn{2}{|c|}{ 787 } & ,019 & ,201 & 250 & 227 \\
\hline
\end{tabular}

a. Grup Değişkeni: medenihal

Mann Whitney-U Test $p<0.05$

Tablo 9'da görüldüğgü üzere örneklem grubu akademisyenlerin akademik etik değerler alt boyut ortalamalarının medeni duruma göre değişip değişmediğini tespit etmek için mann whitney-u testi uygulanmıştır. Elde edilen sonuçlara göre \% 95 anlam düzeyinde $(p<(\alpha=0.05))$ sadece meslektaşa yönelik değerler boyutunun ortalamasının medeni durum değişkeninden etkilendiği tespit edilmiştir.

Tablo 10. Yaş Değişkeni İçin Kruskal-Wallis Testi Sonuçları

\begin{tabular}{|c|c|c|c|c|c|}
\hline & & $\mathbf{N}$ & Ortalama & Standart Sapma & Standart Hata \\
\hline \multirow[t]{9}{*}{ BAYD } & $25-29$ & 154 & 20,2857 & 3,91029 & ,31510 \\
\hline & $30-34$ & 75 & 20,8000 & 4,57076 & ,52779 \\
\hline & $35-39$ & 107 & 20,8411 & 3,92657 & ,37960 \\
\hline & $40-44$ & 52 & 21,0577 & 4,78729 & ,66388 \\
\hline & $45-49$ & 97 & 20,1031 & 4,14951 & ,42132 \\
\hline & $50-54$ & 65 & 20,0154 & 3,86285 & ,47913 \\
\hline & $55-59$ & 30 & 21,4667 & 3,20273 & ,58474 \\
\hline & $60-64$ & 7 & 20,0000 & ,00000 & ,00000 \\
\hline & Total & 587 & 20,5179 & 4,06780 & , 16790 \\
\hline \multirow[t]{9}{*}{ MYD } & $25-29$ & 154 & 35,7208 & 5,69198 & 45867 \\
\hline & $30-34$ & 75 & 35,4267 & 6,44136 & ,74378 \\
\hline & $35-39$ & 107 & 37,1869 & 4,69671 & ,45405 \\
\hline & $40-44$ & 52 & 35,3654 & 6,29979 & 87362 \\
\hline & $45-49$ & 97 & 38,7938 & 6,01030 & 61025 \\
\hline & $50-54$ & 65 & 35,9385 & 6,01269 & 74578 \\
\hline & $55-59$ & 30 & 37,3000 & 5,52206 & 1,00818 \\
\hline & $60-64$ & 7 & 39,0000 & ,00000 & ,00000 \\
\hline & Total & 587 & 36,5707 & 5,83385 & 24079 \\
\hline \multirow[t]{2}{*}{ CKYD } & 25-29 & 154 & 28,7468 & 5,28478 & ,42586 \\
\hline & $30-34$ & 75 & 28,8667 & 6,26732 & 72369 \\
\hline
\end{tabular}




\begin{tabular}{|c|c|c|c|c|c|}
\hline & $35-39$ & 107 & 28,8785 & 5,12800 & ,49574 \\
\hline & $\begin{array}{l}40-44 \\
\end{array}$ & 52 & 27,4231 & 5,81191 & 80597 \\
\hline & $45-49$ & 97 & 30,9381 & 6,02221 & ,61146 \\
\hline & 50-54 & 65 & 28,7385 & 5,67141 & ,70345 \\
\hline & 55-59 & 30 & 30,4667 & 6,60581 & 1,20605 \\
\hline & $60-64$ & 7 & 33,0000 & , 00000 & ,00000 \\
\hline & Total & 587 & 29,1687 & 5,71900 & ,23605 \\
\hline \multirow[t]{9}{*}{ TYD } & $25-29$ & 154 & 28,3182 & 4,40247 & ,35476 \\
\hline & $30-34$ & 75 & 26,7600 & 5,37220 & 62033 \\
\hline & $35-39$ & 107 & 28,6729 & 4,41860 & ,42716 \\
\hline & $40-44$ & 52 & 27,5769 & 4,61178 & ,63954 \\
\hline & $45-49$ & 97 & 29,5464 & 5,73008 & ,58180 \\
\hline & 50-54 & 65 & 29,0000 & 5,09595 & 63208 \\
\hline & 55-59 & 30 & 29,7333 & 5,48310 & 1,00107 \\
\hline & $60-64$ & 7 & 26,0000 & ,00000 & ,00000 \\
\hline & Total & 587 & 28,4412 & 4,96244 & 20482 \\
\hline \multirow[t]{9}{*}{ ÖSYD } & $25-29$ & 154 & 56,3896 & 6,06427 & , 48867 \\
\hline & $30-34$ & 75 & 55,6933 & 8,22319 & ,94953 \\
\hline & 35-39 & 107 & 57,9813 & 5,03381 & ,48664 \\
\hline & $40-44$ & 52 & 55,4038 & 7,53621 & 1,04508 \\
\hline & $45-49$ & 97 & 59,3814 & 6,39082 & 64889 \\
\hline & $50-54$ & 65 & 57,6923 & 7,48733 & ,92869 \\
\hline & $55-59$ & 30 & 58,4667 & 5,73996 & 1,04797 \\
\hline & $60-64$ & 7 & 58,0000 & ,00000 & , 00000 \\
\hline & Total & 587 & 57,2675 & 6,62360 & ,27339 \\
\hline \multicolumn{6}{|c|}{ Test İstatistikleri, ${ }^{\mathrm{b}}$} \\
\hline & BAYD & MYD & CKYD & TYD & ÖSYD \\
\hline Chi-Square & 7,825 & 22,550 & 23,545 & 19,961 & 21,223 \\
\hline $\mathrm{df}$ & 7 & 7 & 7 & 7 & 7 \\
\hline Asymp. Sig. & 348 & ,002 & ,001 & ,006 & ,003 \\
\hline \multicolumn{6}{|c|}{ a. Kruskal Wallis Test } \\
\hline \multicolumn{6}{|c|}{ b. Grup Değişkeni: yaş } \\
\hline
\end{tabular}

Tablo 10'da görüldüğü üzere örneklem grubunu oluşturan akademisyenlerin akademik etik değerler alt boyut ortalamalarının yaş değişkenine göre değişip değişmediğini tespit etmek için kruskal-wallis testi uygulanmıştır. Elde edilen sonuçlara göre \% 95 anlam düzeyinde sadece bilimsel araştırmaya yönelik değerler boyutunun ortalamasının yaş değişkeninden etkilenmediği tespit edilmiştir. Anlamlılık değerleri $(p>(\alpha=0.05))$ olduğu için yaş değişkeni bu alt boyutu etkilememektedir. Meslektaşa yönelik değerler, çalışılan kuruma yönelik değerler, topluma yönelik değerler ve öğretim sürecine yönelik değerler alt boyutlarının ortalamasının 
yaş değişkeninden etkilendiği tespit edilmiştir. Bunu takiben farklılık olduğu tespit edilen alt boyutlarda farklılığı oluşturan yaş gruplarını tespit etmek için mann whitney-u testi uygulanmış ve farklılık oluşturanlar Tablo 11'de belirtilmiştir.

Tablo 11. Farklılık Oluşturan Yaş Grupları Mann Whitney-U Testi Sonuçları

\begin{tabular}{ll}
\hline Alt boyutlar & Yaş Grupları \\
\hline \multirow{3}{*}{ Meslektaşa yönelik değerler } & 25-29 ile 45-49 Yaş Grubu \\
\cline { 2 - 2 } & \begin{tabular}{l} 
30-34 ile 45-49 Yaş Grubu \\
\cline { 2 - 2 }
\end{tabular} \\
\hline Çalışı-44 ile 45-49 Yaş Grubu \\
\hline Topluma yönelik değerler & 40 ile 50-54 Yaş Grubu \\
\hline \multirow{2}{*}{ Öğretim sürecine yönelik değerler } & 30-34 ile 45-49 Yaş Grubu \\
\hline & 25-29 ile 45-49 Yaş Grubu \\
\hline & 30-34 ile 45-49 Yaş Grubu \\
\hline
\end{tabular}

Tablo 12' de görüldüğü üzere örneklem grubunu oluşturan akademisyenlerin akademik etik değerler alt boyut ortalamalarının yurt dişı görev değişkenine göre değişip değişmediğini tespit etmek için mann whitney$\mathrm{u}$ testi uygulanmıştır. Elde edilen sonuçlara göre \% 95 anlam düzeyinde $(p<(\alpha=0.05))$ Bilimsel araştırmaya yönelik değerler boyutunun ortalamasının yurt dişı görev değişkeninden etkilendiği tespit edilmiştir. Diğer tüm alt boyutların ortalamasının medeni durum değişkeninden etkilenmediği tespit edilmiştir.

Tablo 12. Yurt Dışı Görev Değişkeni İçin Mann Whitney-U Testi Sonuçları Grup İstatistikleri

\begin{tabular}{llllll}
\hline & $\begin{array}{l}\text { Yurt Dişı } \\
\text { Görev }\end{array}$ & $\mathbf{N}$ & Ortalama & $\begin{array}{l}\text { Standart } \\
\text { Sapma }\end{array}$ & $\begin{array}{l}\text { Standart } \\
\text { Hata }\end{array}$ \\
\hline \multirow{2}{*}{ BAYD } & Evet & 118 & 21,1525 & 3,74081 &, 34437 \\
\cline { 2 - 6 } & Hayır & 469 & 20,3582 & 4,13444 &, 19091 \\
\hline \multirow{2}{*}{ MYD } & Evet & 118 & 36,6102 & 5,43498 &, 50033 \\
\cline { 2 - 6 } & Hayır & 469 & 36,5608 & 5,93546 &, 27407 \\
\hline CKYD & Evet & 118 & 28,7119 & 5,75289 &, 52960 \\
\cline { 2 - 6 } & Hayır & 469 & 29,2836 & 5,71085 &, 26370 \\
\hline \multirow{2}{*}{ TYD } & Evet & 118 & 28,0847 & 4,50370 &, 41460 \\
\cline { 2 - 6 } & Hayır & 469 & 28,5309 & 5,07188 &, 23420 \\
\hline ÖSYD & Evet & 118 & 57,2119 & 6,17529 &, 56848 \\
\cline { 2 - 6 } & Hayır & 469 & 57,2814 & 6,73790 &, 31113
\end{tabular}




\begin{tabular}{llllll}
\hline Test İstatistikleri & \multicolumn{5}{l}{} \\
\hline & BAYD & MYD & CKYD & TYD & ÖSYD \\
\hline $\begin{array}{l}\text { Mann- } \\
\text { WhitneyU }\end{array}$ & 24003,500 & 27396,000 & 25847,500 & 25958,000 & 27086,500 \\
\hline Wilcoxon W & & & & & \\
\hline Z & 134218,500 & 34417,000 & 32868,500 & 32979,000 & 34107,500 \\
\hline Asymp. Sig. (2-tailed) & $-2,241$ &,- 168 & $-1,132$ & $-1,049$ &,- 356 \\
\hline
\end{tabular}

a. Grup Değişkeni: yurtdışıörev

Mann Whitney-U Test $p<0.05$

13. Meslekteki Kıdem Yılı Değişkeni İçin Kruskal-Wallis Testi Sonuçları

\begin{tabular}{|c|c|c|c|c|c|}
\hline & & $\mathbf{N}$ & Ortalama & Standart Sapma & Standart Hata \\
\hline \multirow[t]{6}{*}{ BAYD } & $1-5$ & 190 & 20,4316 & 4,31351 & ,31294 \\
\hline & $6-10$ & 89 & 20,7416 & 4,07745 & ,43221 \\
\hline & $11-15$ & 100 & 20,9000 & 4,40959 & ,44096 \\
\hline & $16-20$ & 94 & 20,2447 & 3,82883 & ,39491 \\
\hline & $20+$ & 93 & 20,2796 & 3,43057 & ,35573 \\
\hline & Total & 566 & 20,5071 & 4,07528 & ,17130 \\
\hline \multirow[t]{6}{*}{ MYD } & $1-5$ & 190 & 35,1053 & 6,08228 & ,44126 \\
\hline & $6-10$ & 89 & 36,8090 & 5,04497 & ,53477 \\
\hline & $11-15$ & 100 & 37,3600 & 5,58230 & ,55823 \\
\hline & $16-20$ & 94 & 38,4043 & 6,40618 & 66075 \\
\hline & $20+$ & 93 & 36,6022 & 5,57974 & ,57859 \\
\hline & Total & 566 & 36,5654 & 5,91819 & ,24876 \\
\hline \multirow[t]{6}{*}{ CKYD } & $1-5$ & 190 & 28,0474 & 5,32369 & ,38622 \\
\hline & $6-10$ & 89 & 29,1685 & 5,35180 & ,56729 \\
\hline & $11-15$ & 100 & 29,3800 & 5,93531 & ,59353 \\
\hline & $16-20$ & 94 & 30,8830 & 6,40036 & 66015 \\
\hline & $20+$ & 93 & 29,3763 & 5,64130 & ,58498 \\
\hline & Total & 566 & 29,1484 & 5,74156 & ,24134 \\
\hline \multirow[t]{6}{*}{ TYD } & $1-5$ & 190 & 27,9684 & 4,53430 & ,32895 \\
\hline & $6-10$ & 89 & 28,6180 & 4,17380 & ,44242 \\
\hline & $11-15$ & 100 & 27,8000 & 5,29723 & ,52972 \\
\hline & $16-20$ & 94 & 29,3191 & 5,95541 & 61425 \\
\hline & $20+$ & 93 & 28,7957 & 5,21611 & ,54089 \\
\hline & Total & 566 & 28,4011 & 5,00760 & 21049 \\
\hline \multirow[t]{6}{*}{ ÖSYD } & $1-5$ & 190 & 56,3421 & 6,89251 & ,50004 \\
\hline & $6-10$ & 89 & 57,7753 & 5,58967 & ,59250 \\
\hline & $11-15$ & 100 & 56,7800 & 6,23704 & 62370 \\
\hline & $16-20$ & 94 & 58,2447 & 7,32015 & ,75502 \\
\hline & $20+$ & 93 & 57,8280 & 6,67511 & 69218 \\
\hline & Total & 566 & 57,2049 & 6,65033 & 27953 \\
\hline
\end{tabular}


Test İstatistikleri, ${ }^{, b}$

\begin{tabular}{llllll}
\hline & BAYD & MYD & CKYD & TYD & ÖSYD \\
\hline Chi-Square & 3,090 & 23,186 & 13,702 & 5,462 & 6,596 \\
\hline df & 4 & 4 & 4 & 4 & 4 \\
\hline Asymp. Sig. &, 543 &, 000 &, 008 &, 243 &, 159 \\
\hline a. Kruskal Wallis Test & & & & \\
\hline b. Grup Değişkeni: mesleki kıdem yılı & & & \\
\hline
\end{tabular}

${ }^{a}$ Kruskal-Wallis Test $p<0.05$

Tablo 13’ te görüldüğgü üzere örneklem grubu akademisyenlerin akademik etik değerler alt boyut ortalamalarının mesleki kıdem yılı değişkenine göre değişip değişmediğini tespit etmek için kruskal-wallis testi uygulanmıştır. Elde edilen sonuçlara göre \% 95 anlam düzeyinde

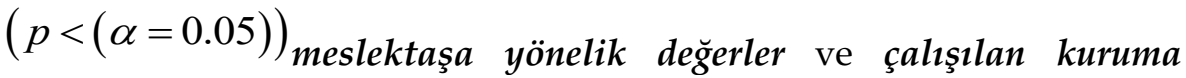
yönelik değerler alt boyutlarının ortalamasının mesleki kıdem yılı değişkeninden etkilendiği tespit edilmiştir. Farklılık olduğu tespit edilen meslektaşa yönelik değerler ve çalışılan kuruma yönelik değerler alt boyutlarında farklılığı oluşturan mesleki kıdem yılı gruplarını tespit etmek için mann whitney-u testi uygulanmış ve farklılık oluşturanlar Tablo 14'de belirtilmiştir.

Tablo 14. Farklılık Oluşturan Mesleki Kıdem Yılı Mann Whitney-U Testi Sonuçları

\begin{tabular}{ll}
\hline Alt boyutlar & Mesleki Kıdem Yilı \\
\hline \multirow{2}{*}{ Meslektaşa yönelik değerler } & $1-5$ ile 11-15 Yıl \\
\cline { 2 - 2 } & 1-5 ile 16-20 Yıl \\
\hline Çalışılan kuruma yönelik değerler & $1-5$ ile 16-20 Yıl \\
\hline
\end{tabular}

Tablo 15. Branş Değişkeni İçin Kruskal-Wallis Testi Sonuçlar

\begin{tabular}{llllll}
\hline \multirow{2}{*}{ BAYD } & & N & Ortalama & Standart Sapma & Standart Hata \\
\cline { 2 - 6 } & İktisat & 38 & 19,6316 & 4,62321 &, 74998 \\
\cline { 2 - 6 } & İşletme & 79 & 20,4051 & 3,68127 &, 41418 \\
\cline { 2 - 6 } & Mühendis & 247 & 20,4615 & 4,11293 &, 26170 \\
\cline { 2 - 6 } & Sağlı & 188 & 20,8777 & 4,12387 &, 30076 \\
\cline { 2 - 6 } & Tarih & 6 & 20,0000 &, 00000 &, 00000 \\
\cline { 2 - 6 } & Felsefe & 7 & 19,5714 & 5,12696 &, 793781 \\
\cline { 2 - 6 } & Uluslararas İlişkiler & 22 & 20,4545 & 3,68688 &, 16790 \\
\cline { 2 - 6 } & Total & 587 & 20,5179 & 4,06780 &, 63890 \\
\hline \multirow{2}{*}{ MYD } & İktisat & 38 & 38,2105 & 3,32198 &, 35871
\end{tabular}




\begin{tabular}{|c|c|c|c|c|c|}
\hline & Sağlik & 188 & 36,3351 & 6,27613 & ,45773 \\
\hline & Tarih & 6 & 39,0000 & ,00000 & 00000 \\
\hline & Felsefe & 7 & 34,2857 & 7,58758 & 2,86784 \\
\hline & Uluslararası İlişkiler & 22 & 36,5000 & 6,43465 & 1,37187 \\
\hline & Total & 587 & 36,5707 & 5,83385 & 24079 \\
\hline \multirow[t]{8}{*}{ CKYD } & İktisat & 38 & 29,1842 & 4,56103 & ,73990 \\
\hline & İşletme & 79 & 29,9747 & 5,43015 & 61094 \\
\hline & Mühendis & 247 & 28,8745 & 5,52493 & ,35154 \\
\hline & Sağlik & 188 & 29,1809 & 6,25648 & 45630 \\
\hline & Tarih & 6 & 33,0000 & ,00000 & ,00000 \\
\hline & Felsefe & 7 & 25,7143 & 7,60952 & 2,87613 \\
\hline & Uluslararası İlişkiler & 22 & 29,5000 & 5,66316 & 1,20739 \\
\hline & Total & 587 & 29,1687 & 5,71900 & ,23605 \\
\hline \multirow[t]{8}{*}{ TYD } & İktisat & 38 & 29,0789 & 4,51653 & 73268 \\
\hline & İşletme & 79 & 30,1013 & 4,87693 & ,54870 \\
\hline & Mühendis & 247 & 28,0121 & 4,70986 & ,29968 \\
\hline & Sağlik & 188 & 28,2766 & 5,28727 & ,38561 \\
\hline & Tarih & 6 & 26,0000 & ,00000 & , 00000 \\
\hline & Felsefe & 7 & 27,7143 & 5,96418 & 2,25425 \\
\hline & Uluslararası İlişkiler & 22 & 28,5000 & 5,34300 & 1,13913 \\
\hline & Total & 587 & 28,4412 & 4,96244 & 20482 \\
\hline \multirow[t]{8}{*}{ ÖSYD } & İktisat & 38 & 59,0789 & 4,35816 & 70699 \\
\hline & İşletme & 79 & 58,2152 & 6,85878 & ,77167 \\
\hline & Mühendis & 247 & 56,9879 & 6,51670 & 41465 \\
\hline & Sağlik & 188 & 56,9840 & 6,89220 & ,50267 \\
\hline & Tarih & 6 & 58,0000 & ,00000 & ,00000 \\
\hline & Felsefe & 7 & 55,7143 & 10,16061 & 3,84035 \\
\hline & Uluslararası İlişkiler & 22 & 56,5909 & 7,32679 & 1,56208 \\
\hline & Total & 587 & 57,2675 & 6,62360 & 27339 \\
\hline \multicolumn{6}{|c|}{ Test İstatistikleri, } \\
\hline & BAYD & MYD & CKYD & TYD & ÖSYD \\
\hline Chi-Square & 2,805 & 8,072 & 8,412 & 15,890 & 5,192 \\
\hline df & 6 & 6 & 6 & 6 & 6 \\
\hline Asymp. Sig. & . 833 & ,233 & ,209 &, 014 &, 519 \\
\hline \multicolumn{6}{|c|}{ a. Kruskal Wallis Test } \\
\hline \multicolumn{6}{|c|}{ b. Grup Değişkeni: branş } \\
\hline
\end{tabular}

Tablo 15'te görüldüğü üzere örneklem grubunu oluşturan akademisyenlerin akademik etik değerler alt boyut ortalamalarının branş değişkenine göre değişip değişmediğini tespit etmek için kruskal-wallis testi uygulanmış, sonuçlara göre \% 95 anlam düzeyinde sadece topluma yönelik değerler boyutunun ortalamasının branş değişkeninden etkilendiği tespit edilmiştir. Anlamlılık değerleri $(p<(\alpha=0.05))$ olduğu için branş 
değişkeni bu alt boyutu etkilemektedir. Sonrasında farklılık olduğu tespit edilen topluma yönelik değerler alt boyutunda farklılığ oluşturan branş gruplarını tespit etmek için mann whitney-u testi uygulanmış ve farklılık oluşturanlar Tablo 16.'da belirtilmiştir.

Tablo 16. Farklılık Oluşturan Branş Mann Whitney-U Testi Sonuçları

\begin{tabular}{ll}
\hline Alt boyut & Branşlar \\
\hline Topluma yönelik değerler & Mühendis ile İşletme \\
\hline
\end{tabular}

\section{Sonuç}

Her meslekte olduğu gibi akademisyenlik mesleğinde de mesleki etik en temel gereklilik hatta zorunluluktur. Akademik etik boyutları akademisyenlere yol göstermektedir. Önemi büyük olan konu ile ilgili literatürde nitel ve nicel çalışmaların sinırlı olduğu görülmektedir. Bu nedenle Türkiye' de bulunan üniversitelerde görevli akademisyenlerin akademik etik değer algı ve tutum düzeylerinin belirlenmesi ve bu düzeylerin demografik değişkenlerine göre durumu belirlenmeye çalışılmıştır.

Araştırma kapsamında kullanılan akademik etik değerler ölçeğinin alt boyutlarını belirlemek için açıklayıcı faktör analizi yapılmış ve toplam varyansı \% 67,434 olan beş alt faktör oluşmuştur. Birinci faktöre mesleğe yönelik değerler (MYD), 2. Faktöre Bilimsel araştırmaya yönelik değerler (BAYD), 3. Faktöre Çalışılan kuruma yönelik değerler (CKYD), 4. Faktöre Öğretim sürecine yönelik değerler (ÖSYD), 5. Faktör Topluma yönelik değerler (TYD) adı verilmiştir. Açıklayıcı ve doğrulayıcı faktör analizleri sonucunda faktörlerin yüksek değerler aldığı görülmüştür. Yapılan korelasyon analizi sonuçlarına göre, akademik etik değerler ölçeğinin her bir alt boyutunun birbirleriyle pozitif yönlü ve anlamlı ilişkisi olduğu görülmüştür. En yüksek ilişki $(, 795)$ çalışılan kuruma yönelik değerler ile meslektaşa yönelik değerler arasındadır.

Araştırma kapsamında yer alan akademisyenlerin, akademik etik değerler alt boyut ortalamalarının demografik değişkenlerden olan cinsiyete göre değişip değişmediğini tespit etmek için yapılan Mann Whitney $\mathrm{U}$ testi sonucuna göre, meslektaşa yönelik değerler ve öğretim sürecine yönelik değerler boyutlarının ortalamasının cinsiyet değişkeninden etkilendiği tespit edilmiştir. Buna göre, " $\mathrm{H}_{1}=$ Akademisyenlerin akademik 
etik değerleri alg1 ve tutum düzeyleri cinsiyet değişkenine göre farklılık göstermektedir" hipotezi kabul edilmiştir. Literatürde etik değerlerin cinsiyete göre farklılık gösterdiği sonucuna ulaşılmış çalışmalar mevcuttur (Cohen, vd., 1998; Özyer ve Azizoğlu, 2010; Pierce ve Sweeney, 2010; Erturhan ve Filizöz, 2011). Meslektaşa yönelik değerler boyutunun ortalamasının medeni durum değişkeninden etkilendiği tespit edilmiştir. Buna göre, " $\mathrm{H}_{2}=$ Akademisyenlerin akademik etik değerleri alg1 ve tutum düzeyleri medeniyet durumu değişkenine göre farklılık göstermektedir" hipotezi kabul edilmiştir. Meslektaşa yönelik değerler, çalışılan kuruma yönelik değerler, topluma yönelik değerler ve öğretim sürecine yönelik değerler alt boyutlarının ortalamasının yaş değişkeninden etkilendiği tespit edilmiştir. Buna göre, " $\mathrm{H}_{3}=$ Akademisyenlerin akademik etik değerleri alg1 ve tutum düzeyleri yaş değişkenine göre farklılık göstermektedir" hipotezi kabul edilmiştir. Literatürde yaş değişkeninin etiğe uygun davranma eğilimini etkilediği sonucuna ulaşmış benzer çalışmalar bulunmaktadır (Çobanoğlu vd., 2005). Elde edilen sonuçlara göre bilimsel araştırmaya yönelik değerler boyutunun ortalamasının yurt dışı görev değişkeninden etkilendiği tespit edilmiştir. Buna göre, " $\mathrm{H}_{4}=$ Akademisyenlerin akademik etik değerleri algı ve tutum düzeyleri yurt dişı görev değişkenine göre farklılık göstermektedir" hipotezi kabul edilmiştir. Meslektaşa yönelik değerler ve çalışılan kuruma yönelik değerler alt boyutlarının ortalamasının mesleki kıdem yılı değişkeninden etkilendiği tespit edilmiştir. Topluma yönelik değerler boyutunun ortalamasının branş değişkeninden etkilendiği tespit edilmiştir. Buna göre, " $\mathrm{H}_{5}=$ Akademisyenlerin akademik etik değerleri algı ve tutum düzeyleri mesleki kıdem yılı değişkenine göre farklılık göstermektedir ve $\mathrm{H}_{6}=$ Akademisyenlerin akademik etik değerleri alg1 ve tutum düzeyleri branş değişkenine göre farklılık göstermektedir" hipotezleri kabul edilmiştir. Literatürde etik konulu ve akademisyenlerin bilimsel araştırma etiği ile ilgili pekçok çalışma bulunmasına rağmen, tüm akademik etik değerlerine yönelik akademisyenlerin alg1 ve tutumlarının ölçüldüğü (nicel ve nitel) çalışma sayısının sınırlı olduğu görülmüştür (Maya, 2013; Sevim, 2014; Aydın vd., 2014; Kırkkılıç vd., 2015). Bu çalışmanın literatüre katkı sağlayacağı düşünülmektedir.

Elde edilen sonuçlara göre, akademik etik değerler araştırma örneklemini oluşturan akademisyenlerin akademik etik değerleri algı ve tutumları demografik değişkenlere göre farklılık göstermektedir. Halbuki 
mesleki etik ilkeler, demografik değişkenlere göre farklılık taşımamalı evrensellik göstermelidir. Bu nedenle akademik etik değerlerinden eğitim ve seminerlerle, akademisyenlerin haberdar olması ve konunun daha iyi anlaşılması ve tutumlara dönüştürülmesi sağlanmalı, uyulmaması durumlarında kişiler arasında ayrım yapılmaksızın yaptırımlar uygulanmalıdır. Bununla birlikte akademisyenler eğitim-öğretim sürecinde öğrencilerine örnek teşkil etmektedir. Öğrenciler eğitim-öğretim sürecini tamamlayıp iş hayatına atıldıklarında öğrendiklerini uygulamaya geçmektedirler. Etik konularda duyarlı bireyler olarak yetişmeleri için bu süreçte akademisyenler tarafından hasas davranılmalı ve örnek olunmalıdır. Öte yandan her birey gibi akademisyenlerin de etik değerleri algılayış biçimleri yaşadıkları toplumsal kültür, hukuk, din vb. etkilenmektedir. Bu nedenle toplumsal anlamda etik değerlerin yerleşmesi için küçük yaşlardan itibaren konuya önem verilmeli ve eğitimlerle desteklenmelidir.

Araştırma örneklemini zaman ve ekonomik sınırlılıklardan dolayı dokuz devlet üniversitesinin akademisyen çalışanları oluşturmuştur. Türkiye'de faaliyet gösteren tüm üniversitelerin esas alındığı bir çalışma ile kapsamın genişletilmesi daha genel bilgilere ulaşılmasını sağlayabilecektir. Aynı zamanda devlet ve özel üniversitelerde işleyişin karşılaştırılmasına imkan da sağlayabilecektir. 


\title{
EXTENDED ABSTRACT
}

\section{Professional Ethics And A Quantitative Investigation On The Ethical Values Of Academicians}

\author{
Meral Erdirençelebi - Berrin Filizöz \\ Necmettin Erbakan University, Cumhuriyet University
}

Today, despite the increasing interest in business ethics, ethical problems in business life continue to increase. In today's conditions where social moral decay is experienced, the concept of ethics must be kept dynamic, understood and applied by all community members. Acting on the principles of professional ethics which constitutes one of the fields of business ethics brings success in competitive conditions. As a result of the technological developments, the transformation of the social structure into an information society has made it compulsory for all activities to be information-oriented. As a matter of fact, the people dealing with knowledge most frequently in society are academicians who are part of science. Academic ethics dimensions guide academicians. Although there are studies on scientific research ethics in the literature (Koklu, 2003; Bulbul, 2004; Ruacan, 2005; Buken, 2006; Aydin, 2006; Ucak ve Birinci, 2008; Odabas, 2015; Ozcan and Balci, 2016), it is seen that there are limited number of studies (quantitative and qualitative) on academicians' opinions about academic ethics (Maya, 2013; Sevim, 2014; Aydin et al., 2014; Kirkkiliç et al., 2015). From this point forth, determining the academic ethics value levels of academicians working at universities in Turkey, and determining whether these levels differ according to demographic variables was the main purpose of the study.

The following hypotheses were formed in line with the main purpose of the research,:

- $\quad \mathrm{H} 1$ = Academic ethics, perception and attitude levels of academicians vary according to the gender variable.

- $\quad \mathrm{H} 2$ = Academic ethics, perception and attitude levels of academicians vary according to the variable of civilization status. 
- $\quad \mathrm{H} 3=$ Academic ethics, perception and attitude levels of academicians vary according to the age variable.

- $\quad \mathrm{H} 4=$ Academic ethics, perception and attitude levels of academicians vary according to the overseas duty variable.

- $\mathrm{H} 5$ = Academic ethics, perception and attitude levels of academicians vary according to the year of professional seniority variable.

- $\quad \mathrm{H} 6=$ Academic ethics, perception and attitude levels of academicians vary according to the branch variable.

In line with the aim of the research, randomly selected 2500 academicians from 9 out of 112 public universities were tried to be reached. A questionnaire form was distributed to the selected academicians via email or face to face. 13 of the 600 returned questionnaires were removed and the remaining 587 questionnaires were analyzed.

SPSS 22 and LISREL 9.1 were used in the analysis of the data collected within the scope of the research. In order to test the reliability of the scale used in the study, Cronbach's Alpha coefficient was calculated by looking at the item-whole correlation. Frequency analysis, explanatory and confirmatory factor analysis, correlation analysis, Kolmogorov-Smirnov test, Mann Whitney-U test and Kruskal-Wallis test were performed.

Explanatory factor analysis was conducted to determine the sub-dimensions of the academic ethical values scale used in the study and five sub-factors with a total variance of $67,434 \%$ were formed. The first factor is called values for the profession (VFP), the second factor is called values for the scientific research (VFSR), the third factor is called values for the institution worked for (VFIW), the fourth factor is called values for the teaching process (VFTP) and the fifth factor is called values for the society (VFS). As a result of explanatory and confirmatory factor analyzes, it was observed that the factors had high values. According to the results of the correlation analysis, it was found that each sub-dimension of the academic ethical value scale had a positive and significant relationship with each other. The highest relationship $(, 795)$ is between the values for the institution worked for and the values for the colleague.

According to the results of the Mann Whitney U test conducted to determine whether the academic ethics sub-dimension averages of the academicians within the scope of the research change according to gender, which is one of the demographic variables, it was found that the mean 
values for the colleague and values for the teaching process were affected by the gender variable. Accordingly, the hypothesis that "H1 = Academic ethics, perception and attitude levels of academicians differ according to gender" was accepted. In the literature, there are studies that conclude that ethical values differ according to gender (Cohen, et al., 1998; Ozyer and Azizoglu, 2010; Pierce and Sweeney, 2010; Erturhan and Filizoz, 2011). It was found that the average of the dimension of values for the colleague was affected by the marital status variable. Accordingly, the hypothesis that " $\mathrm{H} 2$ = Academic ethics values, perception and attitude levels of academicians differ according to the variable of civilization status" was accepted. It was found that the average of sub-dimensions of values for the colleague, values for the institution worked for, values for the society and values for the teaching process were affected by the age variable. Accordingly, the hypothesis that "H3 = Academic ethics values, perception and attitude levels of academicians differ according to age variable" was accepted. There are similar studies in the literature that have concluded that the age variable affects the tendency to behave ethically (Cobanoglu et al., 2005). According to the results obtained, it was found that the average dimension of the values for the scientific research was influenced by the overseas duty variable. Accordingly, the hypothesis that "H4 = Academic ethics, perception and attitude levels of academicians differ according to the overseas duty variable" was accepted. It was found that the average of the sub-dimensions of the values for the colleague and the values for the institution worked for were affected by the variable of year of professional seniority. It was determined that the average of the values for the society was affected by the branch variable. Accordingly, the hypotheses that " $\mathrm{H} 5$ = Academic ethics values, perception and attitude levels of academicians vary according to the year of professional seniority variable and $\mathrm{H} 6=$ Academic ethics values, perception and attitude levels of academicians differ according to the branch variable" were accepted.

According to the results, academic ethical values differ according to the demographic variables of the academicians who make up the research sample. However, professional ethical principles should not differ according to demographic variables and should show universality. For this reason, academicians should be informed and educated of academic ethics through education and seminars, a better understanding of the issue 
should be ensured, and in case of non-obedience, sanctions should be applied without discrimination. In addition, academicians set an example for their students in the education process. When the students complete the education process and start to work, they apply what they have learned. In this process, to be sensitive in ethical issues, they should be treated sensitively by academicians and academicians should be an example for them. On the other hand, just like every individual, academic ethics values of academicians are affected by the social culture lived in, religion and so on. For this reason, from a young age on, importance should be given to the establishment of ethical values in a social sense and supported with trainings

\section{Kaynakça / References}

Akkaya, M. A. ve Yıldırım, Z. (2017). Akademik bilgi üretimi ve etik, Çankırı Karatekin Üniversitesi Karatekin Edebiyat Fakültesi Dergisi, 5(2), 78-93.

Anonim, (2006). MEGEP: Meslekî eğitim ve öğretim sisteminin gü̧̈lendirilmesi projesi. Tüm Alanlar Meslek Etiği, Ankara.

Aydın, İ. (2006). Sosyal bilimlerde araştırmadan yayına etik değerler. Sosyal Bilimlerde Süreli Yayıncllk, I. Ulusal Kurultay Bildirileri, 71-80.

Aydın, İ., Alkın-Şahin, S. ve Demirkasimoğlu, N. (2014). Üniversitelerde karşılaşılan etik dişı davranışlara iliş̧in akademisyen görüşleri. Akademik Bakış Dergisi, 43, 0-0, https://dergipark.org.tr/tr/pub/abuhsbd/issue/32934.

Baldwin, R. G., Lunceford, C. J., and Vanderlinden, K. E. (2005). Faculty in the middle years: Illuminating an overlooked phase of academic life. The Review of Higher Education, 29(1), 97-118.

Büken, N. Ö. (2006). Türkiye örneğinde akademik dünya ve akademik etik. Hacettepe Tip Dergisi, 37, 164-170.

Bülbül, T. (2004). Bilimsel yayınlarda etik. Pamukkale Üniversitesi Eğitim Fakültesi Dergisi, 15, 53-61.

Cohen, J. R., Pant, L.W. and Sharp. D.J. (1998). The effect of gender and academic discipline diversity on the ethical evaluations, ethical intentions and ethicail orientation of potential public accounting recruits. American Accounting Horizons, 12(3), 250-270. 
Çobanoğlu, N., Haberal B. ve Çağlar, S. (2005). Tibbi araştırma ve yayın konusunda etik duyarlılık araştırması. Türk Tip Dizini, Sağlık Bilimlerinde Süreli Yayıncllk, $101-130$.

Erdem, A. R. (2012). Bilim insanı yetiştirmede etik eğitimi. Yükseköğretim ve Bilim Dergisi/Journal of Higher Education and Science, 2(1), 25-32.

Erdoğmuş, N., Torlak, Ö. ve Tiryaki Bilgin, K. (Eds), (2018). Temelleri ve Uygulamalarıla İş Ahlakı, İgiad Yayınları: 19 İş Ahlakı Kitaplığı: 8, İstanbul.

Erturhan, H. ve Filizöz, B. (2011). İş etiği ve bankacılık sektöründe bir araştırma, C. Ü. İktisadi ve İdari Bilimler Dergisi, 12 (2), 139-157.

Filizöz, B. (2011). Etik ve etiğe ilişkin temel kavramlar. (Ed. Z Sabuncuoğlu), İşletme Etiği, Beta Basım AŞ, İstanbul.

Gerçek, H., Güven, M. H. ve Özdamar, Ş. O. (2011). Yükseköğretim kurumlarında etik ilkeler, sorumluluklar ve davranış kuralları. Yükseköğretim ve Bilim Dergisi, 1(2), 80-88.

Karabay, M. E. (2015). Issletmelerde etik ve etik liderlik, sigortacllik sektöründe bir araştırma. İstanbul:Beta Basım Yayın.

Keskin, D. A. (2018). Mesleki etik kavramlar, ilkeler ve vakalar. (2. Bsm.), İstanbul:Beta Basım Yayın.

Kırkkılıç, H. A., Sevim, O. ve Söylemez, Y. (2015). Akademisyenlerin bilimsel araştırma tutumlarının akademik etik değerler açısından incelenmesi. Erzincan Üniversitesi Sosyal Bilimler Enstitüsü Dergisi, Özel Sayı, 375390.

Köklü, N. (2003). Akademisyenlerin araştırma etiği konusundaki görüşleri. Ĕ̆itim Bilimleri ve Uygulama, 2(4), 137-151.

Maya, İ. (2013). Akademisyenlerin meslek ahlakına aykırı olan davranışlara ilişkin algıları:Çomü Eğitim Fakültesi örneği. Turkish Studies- International Periodical For The Languages, Literature and History of TurkishorTurkic, 8(6), 491-509.

Mirze, S. K. (2010), İşletme. Literatür Yayıncılık, İstanbul.

Odabaş, H. (2015) Akademisyenlerin yayıncılık etiği farkındalığı ve eğilimleri: Atatürk Üniversitesi örneği. (Ed. İ. Keskin, Ş.N. Somer, N. Oğuz), İsmet Binark Armağanı, içinde (s.317-327).Türk Edebiyatı Vakfı Yayınları, Yayın Numarası: 179,

Owen, P. R. and Zwahr-Castro, J. (2007). Boundary issues in Academia: student perceptions of faculty-student boundary crossing. EthicsEBehavior, 17(2), 117-129. 
Özcan, M. ve Balcı, Y. (2016). Akademisyenlerin araştırma ve yayın etiğine ilişkin düşünceleri. Türkiye İktisadi Girişim ve İş Ahlâkı Derneği, 9(1), 91-111.

Özyer K. ve Azizoğlu, Ö. (2010). Demografik değişkenlerin kişilerin etik tutumlari üzerindeki etkileri. Ekonomik ve Sosyal Araştırmalar Dergisi, $6(2), 59-84$.

Pierce, B. and Sweeney, B. (2010). The relationship between demographic variables andethical decision making oftrainee accountants. International Journal of Auditing, 14, 79-99, doi:10.1111/j.1099-1123.2009.00404.x.

Ruacan, Ş. (2005). Bilimsel araştırma ve yayınlarda etik ilkeler. Gazi Tip Dergisi, $\quad 16(4), \quad$ 147-149. $\quad$ http://etik.gov.tr/wp-content/uploads/2019/03/sevketruacan-bilimselarastirmaveyayinlardaetik.pdf adresinden erişilmiştir.

Saddleback College. (2011). Faculty code of ethics and professional standards, Retrieved April 16, http://www.saddleback.edu/gov/senate/acsen/ethics.html

Seçer, İ. (2013). SPSS ve LISREL ile pratik veri analizi, analiz ve raporlaştırma, Ankara:Anı Yayıncılık.

Sevim, O. (2014). Akademik etik değerler ölçeğinin geliştirilmesi: güvenirlik ve geçerlilik çalışması. Turkish Studies- International Periodical For The Languages, 9(6), 943-957.

Şenturan, Ş. (2014). Örnek olaylarla örgütsel davranış. İstanbul:Beta Basım AŞ.

Tülübaş, T. ve Göktürk, Ş. (2018). Orta kariyer evresinde bulunan akademisyenlerin akademisyenlik mesleğine yönelik görüşleri. Kocaeli Üniversitesi Eğitim Dergisi, 1(1), 35-51.

Uçak, N. Ö. ve Birinci, H. G. (2008). Bilimsel etik ve intihal. Türk Kütüphaneciliği, 22(2), 187-204.

Ülgen, H. ve Mirze, S. K. (2004). İşletmelerde stratejik yönetim. İstanbul:Literatür Yayıncilik.

Usta, A. (2011). Kuramdan uygulamaya kamu yönetiminde etik ve ahlak. Kahramanmaraş Sütçü İmam Üniversitesi İktisadi ve İdari Bilimler Fakültesi Dergisi, 1(2), 39-50.

Yükseköğretim Kurumları Etik Davranış İlkeleri, (2014), 20.04.2019 tarihinde http://www.ktu.edu.tr/dosyalar/02 0000 27533.pdf adresinden erişilmiştir. 


\section{Kaynakça Bilgisi / Citation Information}

Erdirençelebi, M. ve Filizöz, B. (2019). Meslek etiği ve akademisyenlerin etik değerleri üzerine nicel bir araştırma. OPUS-Uluslararası Toplum Araştırmaları Dergisi, 14(20), 1228-1258. DOI: 10.26466/ opus.599983 